\title{
Cash Conversion Cycle and Profitability of Nigerian Small and Medium-Sized Entities: An Empirical Analysis
}

Musa Muhammad Tsagem

Federal College of Education (FCE), Nigeria

Norhani Aripin*

(TISSA-UUM), Universiti Utara Malaysia, Malaysia

Rokiah Ishak

(TISSA-UUM), Universiti Utara Malaysia, Malaysia

*Corresponding author: norhani@uum.edu.my

\section{A R T I C L E I N F O}

Article history:

Received 6 November 2017

Revised form 18 March 2018

Accepted 2 April 2018

Keywords:

Cash conversion cycle, Profitability, Accounts receivable period, Inventory holding period, Accounts payable period

JEL Classifications: M41, G33, L25

\section{A B S T R A C T}

The aim of this study was to investigate the relationship between cash conversion cycle and firm performance of small and medium-sized entities (SMEs) in Nigeria. SMEs are potentials for Nigerian economy growth; contributing to gross domestic product, employment generation, poverty reduction and industrialization. The study employed the panel data regression analysis using financial data from a sample of 311 Nigerian SMEs for the period 20072013. The findings of the study revealed a negative association between cash conversion cycle, inventory holding period and accounts payable period with SMEs profitability; and a statistically significant negative relationship between accounts receivable period and SMEs' profitability. The findings also found a significant positive relationship between firm size, leverage, growth opportunities and firm age and SMEs' profitability. Thus, the result of the study indicates that Nigerian SMEs with a shorter cash conversion cycle and low growth 
opportunities hold more cash. This study contributes to existing literature on the relationship between cash conversion cycle and SMEs' profitability in developing economies. However, this study is limited to non-financial and non-service SMEs.

\section{Introduction}

The traditional approach to efficient working capital management is based on the concept of cash conversion cycle (CCC). The cash conversion cycle concept was first introduced in 1974 by Gitman and modified in 1980 by Richards and Laughlin as an instrument for analysing a firm's cash management and as a predictor of firm outcomes. Put differently, Richards and Laughlin (1980) initiated the working capital management theory based on the traditional cash conversion cycle which measures how well a firm is managing its working capital. According to Gitman (1974) cash conversion cycle is one of the major components of working capital management and a standard for measuring the period between payment of cash for raw materials purchased and collection of cash from customers for credit sales. Similarly, Shin and Soenen (1998), Nobanee et al. (2011), Raheman et al. (2011), and Baños-Caballero et al. (2012) describe cash conversion cycle as an additive and popular measure of efficient working capital management.

Previous scholars such as García-Teruel and Martínez-Solano (2007), Samson et al. (2012) and Baños-Caballero et al. (2012) established that efficient working capital management is most significant to small and medium-sized entities. This is because of the higher proportion of current assets and current liabilities which form the major sources of their external financing. Similarly, findings from most of the studies on working capital management and SME profitability indicate that SMEs are generally subjected to financial constraints (Fazzari \& Petersen, 1993; Howorth et al., 2000) due to their inability to obtain financing in the long-term capital market, poor financial management and their vulnerability to risk (Baños-Caballero et al., 2010; 2012). According to Tsagem, Aripin and Ishak (2015) SMEs have high information asymmetry and low managerial proficiency that affect the owners'/managers' ability to secure external financing for growth. Thus, questionable managerial proficiency and poor working capital management of SMEs made many credit institutions to be more sceptical to give loans to SMEs, which caused problems of inadequate financing for growth and sustainability as compared to large firms listed in the stock markets. 
Recognizing the importance of the SMEs and the challenges of the sector, different policies and programmes have been put in place by different countries, international organizations such as the World Bank and other supporting agencies for SMEs development (Boonpattarakan, 2012). Specifically in Nigeria, since independence, several policies, programmes and initiatives have been put in place by the government as an effort to stimulate SMEs development through infrastructural development, adequate funding and advisory services. However, the Nigerian SMEs are found to be not performing particularly in the areas of employment generation, poverty reduction, provision of goods and services and contribution to Gross Domestic Product (CBN, 2012, SMEDAN/ NBS, 2012). For instance, the SMEs sector's contribution to employment generation in Nigeria is 58\%, 70\% and 60\% for the years 2001, 2007 and 2012 respectively (NBS, 2011; SMEDAN/NBS, 2012). This is against the World Bank benchmark of 95\% for Middle Income Countries (World Bank, 2011). In terms of contribution to GDP, the Nigerian SMEs sector's contribution dropped to $46.54 \%$ in 2012 against $62.1 \%$ and $50 \%$ in 2001 and 2007 respectively. In addition, these figures are far below the World Bank projection of 70\% SMEs contribution to GDP in the Middle Income Countries (World Bank, 2011).

In addition, there have been higher bankruptcy rates among SMEs in Nigeria over the years. This is evident on the failure of HiTV Nig. Ltd., Leventis Store, Stationery Store, Michelin Nig. Ltd., and other firms in the textile industry, food and drinks companies, flourmills and paper mills. Toby (2007), Okpara (2011) and Sunday (2011) affirmed that SMEs' bankruptcy rate is higher within the first $2-5$ years of their establishment. Studies have also showed that five out of ten SMEs failed within the first 12 months of establishment while two survived after ten years and out of every 100 SMEs in the past ten years, only $33 \%$ survived, $39 \%$ failed while $28 \%$ operated at half capacity (Ademola, Olaleye, Olusuyi, \& Edun, 2013). The study further added that the Corporate Affairs Commission (CAC) delisted 35,000 registered business names from the list of active businesses the majority of which were SMEs during the year 2010. These were further affirmed by the Director-General of the Small and Medium-Scale Enterprises Development Agency of Nigeria and the Governor of the Central Bank of Nigeria (CBN, 2012; SMEDAN/NBS, 2012) that the contribution of SMEs to the Nigerian economy was low as compared to its contemporary Asian Emerging Economies such as China, Indonesia, Malaysia, India and Singapore.

One of the major factors identified for SMEs' low performance and consequence failure is poor working capital management. It is believed that inefficiency and poor resources management in which working capital components are included such as cash, inventories, receivables and payables account for SMEs' low performance and bankruptcy in Nigeria. In addition, a studies on the relationship between cash conversion cycle as a measure of efficient working capital management and firm profitability showed mixed findings. For example Shin and Soenen (1998), Deloof (2003), Filbeck and 
Kruenger (2005), Lazaridis and Tryfonidis (2006), Garcia-Teruel and MartinezSolano (2010) and Nobanee, Abdullatif and AlHajjar (2011) found a significant negative relationship between cash conversion cycle and firm's profitability. However, Gill et al. (2010), Muhammad et al. (2010), Abuzayed (2012), Samson et al. (2012) and Charitou, Elfani and Lois (2010) found a positive association between cash conversion cycle and firm's profitability.

Given the significance of cash conversion cycle as a core in efficient working capital management and a standard measure of working capital efficiency, different scholars in the area have different approaches. Some examined the determinants of cash conversion cycle, others studied the optimal level of CCC and its components, while some examined the effects of CCC on the firms' profitability. Therefore, this study was set to extend the work of Nobanee et al. (2011), Takon (2013), Yazdanfar and Öhman (2014) and Mathuva (2014) on the relationship between cash conversion cycle and its components and firm's profitability. The study contributes to the body of knowledge by enriching the existing literature with respect to the scope and methodology applied by the previous studies. For example, Nobanee et al. (2011) examined cash conversion cycle and firm performance of Japanese firms. The study was limited to firms listed on the Tokyo Stock Exchange during the period 1990 to 2004. Data for the study was analysed using the Generalised Method of Moment (GMM) System Estimator. Takon (2013) further examined whether CCC had any significant impact on the return on assets of Nigerian firms. The study was limited to data from 46 quoted firms listed on the Nigerian Stock Exchange during the period of 2000 to 2009. The data for the study was analysed using multiple regression analysis. Mathuva (2014) on the other hand, studied the determinants of cash conversion cycle of Kenyan listed non-financial firms. The study utilised data obtained from 33 publicly-traded firms on the Kenyan Stock Exchange. Similarly, Yazdanfar and Ohman (2013) investigated the impact of cash conversion cycle on the performance of Swedish SMEs for 2008 - 2011. The study applied the unrelated regression model to analyse the cross-sectional data covering SMEs operating in four industries only. The study therefore, suggested further studies to examine the generalisability of the findings to other countries and industries.

Furthermore, it has been observed that literature in relation to cash conversion cycle with SMEs' profitability were little despite the current assets (working capital) constituting more than $60 \%$ of the SMEs' total assets (GarcíaTeruel \& Martínez-Solano, 2007; Samson et al., 2012). Hence, the study provides practical guidance to SME owners/managers, particularly on efficient working capital management (cash conversion cycle) for the improvement of financial management decisions and strategies, including improving the capacity to utilise firms' short-term resources internally and for attaining growth and sustainability coupled with their financial constraints. Therefore, the study focussed on the Nigerian SMEs because of the importance of the sector to the 
Nigerian economic growth, poverty alleviation, employment generation and industrialisation.

The rest of the paper is organised as follows. Section two reviews the existing literature; Section three discusses the methodology of the study; Section four provides the findings of the study and the discussions, and Section five concludes and provides recommendations for future studies.

\section{Literature Review and Hypothesis Development}

Scholars have defined cash conversion cycle differently. For example, according to Richards and Laughlin $(1980,34)$, cash conversion cycle is "the net time interval between actual cash expenditures on a firm's purchase of productive resources and the ultimate recovery of cash receipts from product sales". Stewart (1995) defines it as a standard measure of the average period of time a firm takes to turn a dollar invested in purchasing raw materials into a dollar collected from receivables. Similarly, Deloof (2003), Besley and Brigham (2007), Lazaridis and Tryfonidis (2006), Nobanee et al. (2011), and Takon (2013) describe cash conversion cycle as the time lag between the payments for the purchase of a firm's raw materials to the time of collection of receivables associated with the credit sales. In effect, cash conversion cycle refers to the time-period between the purchase of raw materials, converting to finished goods and to accounts receivable and then to cash. The cycle defines the number of days on average taken by a firm from the purchase of inventories on credit to the time of cash collection from customers. Simply, cash conversion cycle measures a firm's accounts receivable period and inventory holding period versus accounts payable period (Deloof, 2003). The cycle indicates the relationship of the components that make up the cash conversion cycle as in the Figure below.

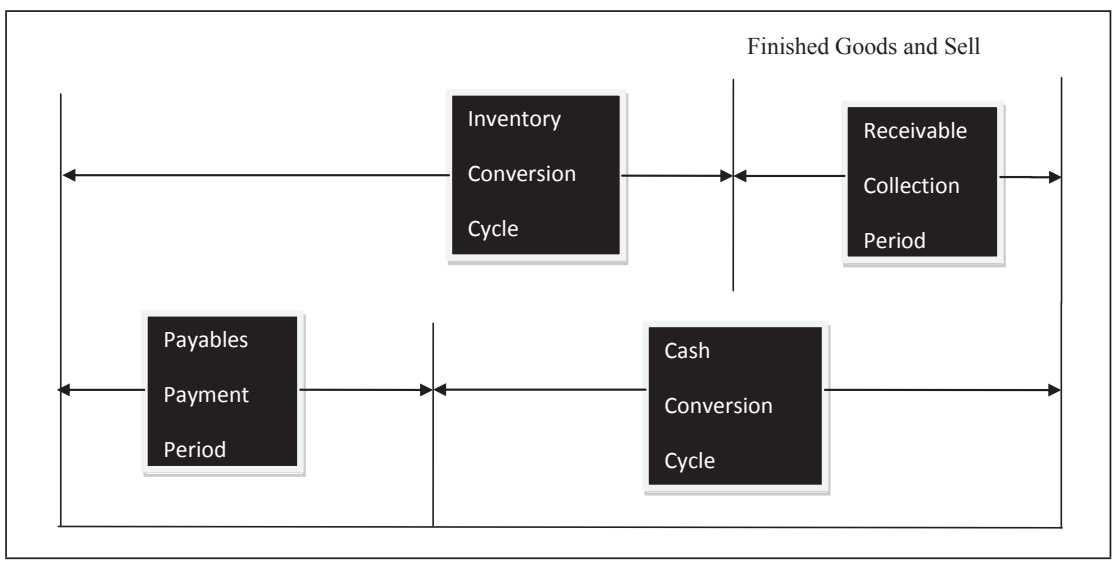

Figure 1. Cash Conversion Cycle 
Traditionally, a shorter cash conversion cycle is associated with an increase in the firm's profitability because of the improvement in the efficient use of working capital whereas longer CCC hurts profitability. This indicates that a firm with shorter CCC is collecting its receivables as quickly as possible and delaying payments to suppliers as much as possible (Shin \& Soenen, 1998; Lazaridis \& Tryfonidis, 2006a). This results in high net present value for the firm's cash flow and relatively high for the firm's value (Nobanee et al., 2011). Cash conversion cycle can be shortened by reducing the time that cash is tied up in the working capital. According to Nobanee et al. (2011) CCC can be shortened by shortening the accounts receivable period through speeding up collections, or by shortening the inventory holding period through quick processing of order and selling of goods to customers or by lengthening the accounts payable period through slowing down of payments to trade creditors. However, shortening the cash conversion cycle could have a negative effect on the firm's operation, which might result in low performance. For example, lengthening the accounts payable period will damage the credit reputation of the firm and reducing the inventory holding period could increase shortage cost and result in loss of good customers. On the other hand, longer cash conversion cycle is associated with higher investment in working capital. Deloof (2003), Gill et al. (2010) and Abuzayed (2012) argued that longer CCC might increase firm profitability due to high sales. Similarly, Shin and Soenen (1998) opined that a firm can have a longer CCC through generous credit policies which increase sales and that may result in higher profitability.

\subsection{Cash Conversion Cycle and SMEs}

Generally, SMEs are faced with significant financial constraints due to their inability to secure external financing. This may not be unconnected with the liability of smallness, high risk and cost involved which results in high failure rate in many small firms. According to Ebben and Johnson (2011) many lenders and investors are reluctant to provide financing to SMEs because of the risk and cost involved. Thus, external financing tends to be difficult and highly expensive to SMEs. In addition to the internal financial constraints, the global financial crisis and credit squeeze are equally threatening the survival of many SMEs particularly in developing economies. Furthermore, SMEs have high information asymmetry and low managerial proficiency that affect the owners'/managers' ability to secure external financing for growth. These relegate them to the use of internally generated funds and short-term resources to finance operations by means of efficient working capital management.

Different scholars used cash conversion cycle in their studies as a working capital management variable and a measure of working capital management efficiency (Nobanee \& Ellili, 2015). For example, Smith and Begemann (1997), 
Deloof (2003), Lazaridis and Tryfonidis (2006), Nobanee et al. (2011), Takon (2013), and Majeed, Makki, Saleem and Aziz (2013) used cash conversion cycle as a variable for measuring working capital in relation to corporate profitability and concluded that cash conversion cycle is the most widely (standard) used measure of working capital management efficiency. It is a common tool for evaluating the liquidity and profitability of a business, especially for small businesses that usually have limited financial resources in comparison to large corporations that have unlimited access to financial markets.

Wilson (1997), in his study, found a strong relationship between efficiency in managing cash conversion cycle and a firm's profitability. Sabri (2012) studied the different working capital management policies and the profitability of 45 Jordanian companies listed on the Amman Stock Exchange between the years 2000 and 2007. The results of the study revealed that there are significant differences between firms with high cash conversion cycle and those with low cash conversion cycle. Similarly, Deloof (2003) investigated the relationship between working capital management and corporate profitability of Belgian firms for the period 1992-1996 and observed that most of the firms have large amounts of cash invested in working capital and large amounts of accounts payable. Therefore, the study affirms that firms with cash shortage may face risk of stock-out and cannot extend large trade credit and most of the sample firms source funds by having large amounts of accounts payable.

Nobanee et al. (2011) analysed the effects of cash conversion cycle on the performance of Japanese firms. The study utilised a sample of 34,771 nonfinancial firms listed on the Tokyo Stock Exchange from 1990 to 2004. The finding of the study revealed a strong negative relationship between the length of the firm's cash conversion cycle and its profitability. This indicates that a shorter cash conversion cycle is associated with higher profitability. Hence, a firm can increase its profitability level by shortening the length of its cash conversion cycle. An efficient cash conversion cycle results in an increase in the firm's profitability, whether of large or small firms (Shin \& Soenen, 1998). Furthermore, a firm with shorter cash conversion cycle may not require external funding and this leads to incurring less borrowing cost and interest expenses, which potentially increase a firm's profitability.

Shin and Soenen (1998) further elucidate that one possible way to increase a firm's profitability and create shareholders' value is by reducing the firm's net trade cycle. Net trade cycle and cash conversion cycle are almost equal where all the three components (receivable, inventory and payable) are expressed as a percentage of sales (Nobanee \& Ellili, 2015). Azam and Muhammad (2011) and Takon (2013) also affirm that cash conversion cycle and net trade cycle reveal a significantly negative association with return on assets and return on equity. Thus, a firm's performance can be improved by shortening both the cash conversion cycle and the net trade cycle. Similarly, Karadagli (2013) examined the profitability effects of cash conversion cycle of 169 Turkish listed firms over 
a period of ten years from 2001 to 2010 . The finding of the study revealed that shortening cash conversion cycle and its single component accounts payable period improved firm's profitability. The study opined that managers could increase firms' profitability by shortening the cash conversion cycle.

In their study, Nobanee and Ellili (2015) examined the working capital management and performance of Kuwait construction companies. The study utilised financial data from a sample of 44 construction companies listed on the Kuwait Stock Exchange over a period of 13 years from 2001 to 2013. The findings of the study revealed a significant positive relationship between net trade cycle and performance of large construction companies, and an insignificant relationship with small construction companies. The study concluded that large construction companies are more efficient in managing their working capital than the small companies.

In contrast, Charitou et al. (2010) used net trade cycle as a measure of working capital management. The study examined the effect of working capital management on the return on investment of all Indonesian firms over the period of 1998-2010. The finding of the study revealed that firm's profitability is positively associated with its net trade cycle. Similarly, Gill et al. (2010), and Abuzayed (2012), in their studies, reported a significantly positive relationship between cash conversion cycle and firm's profitability, which signifies that highly profitable firms give less attention to efficient management of working capital.

To test the effects of working capital management on the firm's profitability, Sharma and Kumar (2011) examined the data from a sample of 263 non-financial firms listed on the Bombay Stock Exchange during the period 2000-2008 using the OLS regression model. The finding of the study revealed that cash conversion cycle and account receivables period exhibit a positive relationship with corporate profitability.

However, Afeef (2011) found an insignificant association between firm's profitability and cash conversion cycle of 40 sample SMEs listed on the KSE for the period of 2003-2008. In addition, Arunkumar and Radharamanan (2012) found that cash velocity is positively correlated with profit before the depreciation of tax account. It appears that if the firms' efficiency in utilisation of cash is increased, its profitability also increases. It also indicates that cash velocity and firm size are positively correlated with the profitability of manufacturing firms in India.

Further, Tsagem, Aripin and Ishak (2015) investigated the impact of working capital management on the profitability of small and medium-sized entities in Nigeria. The study utilised a sample of 47 SMEs drawn from the north-west geographical region of Nigeria over a period of five years from 2008 to 2013. The finding of the study showed a positive relationship between cash conversion cycle and firm's profitability. The study revealed that longer CCC resulted in increasing the firm's profitability through high sales. 
Thus, the inconsistency of the findings by the previous scholars justifies the need for further research to be carried out in the area, and particularly using a large sample and in different environments. In this respect, this study further examined the impact of cash conversion cycle and its components on the profitability of SMEs by reviewing the trend of the phenomenon in an emerging economy with a less developed financial market, like Nigeria. Essentially, this will expand the boundary of knowledge and create more avenues for further investigations.

Based on the problem statement and literature review discussed on the relationship between cash conversion cycle and firm profitability, the hypotheses of the study are stated in null form as follows:

$\mathrm{H}_{1}$ : There is no significant relationship between cash conversion cycle and SMEs profitability in Nigeria.

$\mathrm{H}_{2}$ : There is no significant relationship between each component of cash conversion cycle and SMEs profitability in Nigeria.

\section{Methodology and Research Design}

The methodology used in this study was quantitative based on panel data to report the empirical findings on the relationship between cash conversion cycle as a measure of working capital efficiency and SMEs' profitability. The study analysed data from the annual reports of 311 samples of non-financial and non-services Nigerian SMEs over a period of 7 years (2007-2013). The sample SMEs were selected from across the six Nigeria Geo-political Zones using stratified and convenience sampling techniques. Financial and services SMEs were excluded from the study due to the nature of their business activities. Similarly, firms with missing value and incomplete data of the selected variables over the period of the study were also excluded from the sample.

The main variables of the study included the dependent variable return on assets (ROA) which served as a proxy for SMEs' profitability. The explanatory variables included the cash conversion cycle (CCC) and its components; accounts receivable period (ARP), inventory holding period (IHP) and accounts payable period (APP). To remain consistent with previous studies, the measure for these variables were adopted from Deloof (2003), Padachi (2006), García-Teruel and Martínez-Solano (2007), Mathuva (2010; 2014), Gill et al. (2010), BañosCaballero et al. (2010; 2012), Afeef (2011) and Nobanee et al. (2011). Besides the main variables of the study, a few control variables were introduced which were likely to influence the relationship of the study variables as utilised by Shin and Soenen (1998), Ramachandran and Jankiraman (2009), Okpara (2011), Kaur and Singh (2013) and Tsagem et al. (2015). The four control variables adopted were firm size, leverage, sales growth and firm age. 
Table 1. Variables and Measurement

\begin{tabular}{|c|c|c|c|}
\hline Variables & Measurement & Abbreviations & Type \\
\hline Return on assets & $\begin{array}{l}\text { (Earnings before interest and tax) } \\
\text { / total assets }\end{array}$ & ROA & Dependent \\
\hline $\begin{array}{l}\text { Cash conversion } \\
\text { cycle }\end{array}$ & $\begin{array}{l}\text { Accounts receivable period } \\
+ \text { inventory holding period - } \\
\text { Accounts payable period }\end{array}$ & $\mathrm{CCC}$ & \multirow{5}{*}{ Independent } \\
\hline $\begin{array}{l}\text { Accounts receivable } \\
\text { period }\end{array}$ & $\begin{array}{l}\text { (Accounts receivable / Net sales) } \\
\text { X } 365 \text { days }\end{array}$ & ARP & \\
\hline $\begin{array}{l}\text { Inventory holding } \\
\text { period }\end{array}$ & $\begin{array}{l}\text { (Inventories / Cost of goods sold) } \\
\text { X } 365 \text { days }\end{array}$ & IHP & \\
\hline $\begin{array}{l}\text { Accounts payable } \\
\text { period }\end{array}$ & $\begin{array}{l}\text { (Accounts payable / purchases) X } \\
365 \text { days }\end{array}$ & APP & \\
\hline Firm size & Natural logarithm of total assets & FSIZE & \\
\hline Leverage & Total debt / Total assets & LEV & \multirow[t]{3}{*}{$\begin{array}{l}\text { Control } \\
\text { variables }\end{array}$} \\
\hline Sales growth & $\left(\right.$ Sales $_{1}-$ Sale $\left._{0}\right) /$ Sales $_{0}$ & GROW & \\
\hline Firm age & Date of incorporation to date & FAGE & \\
\hline
\end{tabular}

Consistent with previous studies by Soenen (1993), Nobanee et al. (2011), Ebben and Johnson (2011), Karadagli (2013) and Majeed et al. (2013), the study models are presented as follows:

ROAit $=\beta o+\beta_{1}$ CCCit $+\beta_{2}$ FSIZEit $+\beta_{3}$ LEVit $+\beta_{4} S G R O W i t+\beta_{5}$ FAGEit + Eit.

\section{Results and Discussions}

In this section, the findings of the study are first presented by describing the data using descriptive statistics which give information about the mean, standard deviation, the minimum and maximum of each of the variables of the study. Secondly, an analysis of the correlations among the study variables is presented using the Pearson Correlation Coefficient. Further, regression analysis is used to shed more light on the relationship between cash conversion cycle and SMEs profitability using return on assets (ROA).

Table 2 explores the descriptive analysis of the pooled data obtained from the financial statement of the sample SMEs during the period 2007-2013. The table reports the mean and the standard deviation for each of the variables. Besides, the table includes the minimum and maximum value of each of the variables to show the extreme values achieved by all the variables of the study during the period of the study. 
Table 2. Descriptive Statistics $(n=311: t=7)$

\begin{tabular}{lrrrr}
\hline Variables & Mean & Std. deviation & Minimum & Maximum \\
\hline ROA & 0.15 & 0.11 & 0.01 & 0.95 \\
CCC(days) & 128.95 & 69.72 & 1.00 & 251.00 \\
ARP(days) & 47.24 & 35.05 & 1.00 & 121.00 \\
IHP (days) & 44.05 & 25.80 & 1.00 & 88.00 \\
APP(days) & 68.77 & 45.06 & 1.00 & 151.00 \\
FSIZE (ln) & 15.46 & 1.22 & 12.92 & 23.25 \\
SGROW & 0.39 & 1.49 & -1.00 & 35.01 \\
LEVERAGE & 0.11 & 0.19 & -0.10 & 6.16 \\
FAGE & 10.51 & 6.73 & 7.00 & 41.00 \\
\hline
\end{tabular}

Note. ROA is return on assets; CCC is cash conversion cycle; ARP is accounts receivable period; IHP is inventory holding period; APP is accounts payable period; FSIZE is firm size; SGROW is sales growth; LEVERAGE is leverage and FAGE is firm age.

The dependent variable SMEs return on assets (ROA) has a mean value of 0.15 indicating in average the percentage of returns on total assets of Nigerian SMEs for the period. The minimum value for the ROA shows 0.01 and the maximum value is 0.95 . On average, the cash conversion cycle is 130 days for the sample Nigerian SMEs and a minimum of 1day and a maximum of 251 days. According to Abuzayed (2012) a positive cash conversion cycle indicates the number of days a firm must borrow or tie-up its capital while awaiting payment from customers whereas a negative CCC indicates the number of days a firm has received cash from sales before it pays its trade creditors. The descriptive statistics for the three components of the cash conversion cycle indicates that accounts receivable period has a mean value of 47 days and a minimum and maximum of 1 day and 121 days respectively. The inventory holding period shows an average of 44 days with a minimum and maximum of 1 day and 88 days respectively. This means Nigerian SMEs hold inventories for 44 days on average and at most for 88 days. For the accounts payable period, the mean value was 69 days with a minimum and a maximum of 1 day and 151 days respectively. This means, Nigerian SMEs take 69 days on average to pay their creditors with a maximum of 151 days. This indicates that most Nigerian SMEs prolong payment of their account payables to take advantage of free financing.

Furthermore, the descriptive analyses of the control variables indicate that firm size shows a mean value of 15.46 and sales growth of the study SMEs increases by 39 percent on average annually. The debt to total assets ratio (leverage) is 0.08 which indicates the average ratio of external financing source of the total financing of the study SMEs. This shows that most of the Nigerian SMEs are relying on internal financing sources from the owners and retained 
earnings. Further, it indicates the level of inadequate funding from external sources such as creditors, banks and other financial institutions, which may be attributed to their level of opacity, information asymmetric and poor resources management. Lastly, the average age of the sample SMEs was 11 years, which indicates a high level of bankruptcy and the failure of SMEs during the period of the study.

The results in Table 3 below reveal the correlation coefficient among the study variables. The correlation analysis reveals an insignificant negative association between ROA and CCC and APP, and a significant negative association with ARP. However, the association found between ROA and IHP and with the four control variables (FSIZE, GROW, LEV and FAGE) are all positive and significant. This indicates that cash conversion cycle, accounts payable period and accounts receivable period of the sample SMEs are negatively associated with firm's profitability measured by ROA, whereas inventory holding period revealed a positive association with SMEs' profitability. Similarly, all the four control variables of the study are positively associated with SMEs' profitability at 5\% significant level. This indicates that an increase in firm size measured by natural logarithm of total assets and firm growth opportunities results in increasing the firm's profitability. Similarly, firm age also has significant effects on SMEs' profitability, which indicates that older firms have more profit.

Table 3. Pearson Correlations Coefficient $(\mathrm{N}=2177)$

\begin{tabular}{lccccccccc}
\hline Variables & 1 & 2 & 3 & 4 & 5 & 6 & 7 & 8 & 9 \\
\hline ROA & 1.00 & & & & & & & & \\
CCC & -0.009 & 1.00 & & & & & & & \\
ARP & $-0.08^{* *}$ & $0.44^{* *}$ & 1.00 & & & & & & \\
IHP & 0.03 & $0.38^{* *}$ & $0.25^{* *}$ & 1.00 & & & & & \\
APP & -0.02 & $-0.73^{* *}$ & $0.14^{* *}$ & $0.17^{* *}$ & 1.00 & & & & \\
FSIZE & $0.19^{* *}$ & $0.12^{* *}$ & $0.14^{* *}$ & $0.23^{* *}$ & $0.04^{*}$ & 1.00 & & & \\
SGROW & $0.18^{* *}$ & -0.02 & -0.03 & -0.03 & -0.01 & $0.15^{* *}$ & 1.00 & & \\
LEV & $0.10^{* *}$ & $-0.37^{* *}$ & 0.02 & $0.06^{* *}$ & $0.46^{* *}$ & -0.02 & $0.05^{*}$ & 1.00 & \\
FAGE & $0.11^{* *}$ & $0.08^{* *}$ & $0.05^{*}$ & 0.02 & $-0.04^{*}$ & $0.27^{* *}$ & $0.10^{* *}$ & 0.00 & 1.00 \\
\hline
\end{tabular}

**Correlation is significant at the 0.01 level and *at 0.05 significant level (2-tailed). Note. ROA is Return on Assets; CCC is Cash Conversion Cycle; ARP is Accounts Receivable Period; IHP is inventory holding period; APP is accounts payable period; FSIZE is firm size; SGROW is sales growth; LEVERAGE is leverage and FAGE is firm age.

Besides using the correlation coefficient value, the multicollinearity test was also conducted using the variable inflation factor (VIF) as depicted in Table 4. The result indicates the mean VIF of 1.08, below the threshold of 10, which indicates absence of multicollinearity (Field, 2009). Similarly, the 
result shows the tolerance values above 0.10 and VIF values less than 10 for all the variables. It can be concluded that multicollinearity among independent variables does not have any effect on the regression results especially when one of the advantages of using panel data is to reduce the effects of multicollinearity.

This section presents the results of the findings based on the methodology stated in Section 3. There are different stages for selecting an appropriate regression model in panel data analysis using the STATA software. This study focuses on three static panel data estimation models: the Pooled Ordinary Least Squares (OLS), Fixed Effects (FE) and Random Effects (RE). Each of these models has its underlying assumptions which must be satisfied to obtain unbiased and reliable estimates (Bhaduri, 2013).

Table 4. Regression Analysis

\begin{tabular}{|c|c|c|c|c|}
\hline \multirow{2}{*}{$\begin{array}{l}\text { Explanatory } \\
\text { variables }\end{array}$} & \multirow[t]{2}{*}{ Pooled OLS } & \multirow[t]{2}{*}{ Fixed effects } & \multirow[t]{2}{*}{ Random effects } & \multirow{2}{*}{$\frac{\text { Multicollinearity }}{\text { VIF }}$} \\
\hline & & & & \\
\hline $\mathrm{CCC}$ & $\begin{array}{c}0.00 \\
(-1.04)\end{array}$ & $\begin{array}{c}0.00 \\
(-0.05)\end{array}$ & $\begin{array}{c}0.00 \\
(-0.34)\end{array}$ & 1.19 \\
\hline ARP & $\begin{array}{c}-0.00 \\
(-3.61)^{* * *}\end{array}$ & $\begin{array}{c}-0.00 \\
(-2.15)^{*}\end{array}$ & $\begin{array}{c}-0.00 \\
(-2.97)^{* *}\end{array}$ & 1.04 \\
\hline IHP & $\begin{array}{c}0.00 \\
(-1.59)\end{array}$ & $\begin{array}{c}0.00 \\
(-1.27)\end{array}$ & $\begin{array}{c}0.00 \\
(-1.53)\end{array}$ & 1.02 \\
\hline APP & $\begin{array}{c}0.00 \\
(-0.46)\end{array}$ & $\begin{array}{c}0.00 \\
(-0.67)\end{array}$ & $\begin{array}{c}0.00 \\
(-0.78)\end{array}$ & 1.02 \\
\hline FSIZE & $\begin{array}{c}0.01 \\
(6.53)^{* * *}\end{array}$ & $\begin{array}{c}-0.00 \\
(-0.11)\end{array}$ & $\begin{array}{c}0.01 \\
(4.63) * * *\end{array}$ & 1.14 \\
\hline SGROW & $\begin{array}{c}0.00 \\
(7.36)^{* * *}\end{array}$ & $\begin{array}{c}0.00 \\
(6.63)^{* * * *}\end{array}$ & $\begin{array}{c}0.00 \\
(7.32)^{* * *}\end{array}$ & 1.03 \\
\hline LEV & $\begin{array}{c}0.00 \\
(4.51)^{* * *}\end{array}$ & $\begin{array}{c}0.00 \\
(2.44)^{*}\end{array}$ & $\begin{array}{c}0.00 \\
(3.56)^{* * *}\end{array}$ & 1.12 \\
\hline FAGE & $\begin{array}{c}0.00 \\
(2.19)^{*}\end{array}$ & $\begin{array}{c}0.00 \\
(6.30)^{* * * *}\end{array}$ & $\begin{array}{c}0.00 \\
(3.13)^{* * * *}\end{array}$ & 1.09 \\
\hline Constants & $\begin{array}{c}-0.10 \\
(-3.51)^{* * *}\end{array}$ & $\begin{array}{c}0.04 \\
(-0.870)\end{array}$ & $\begin{array}{c}-0.08 \\
(-2.14)^{*}\end{array}$ & \\
\hline R-square & 0.08 & 0.07 & 0.11 & \\
\hline F-statistics & 23.43 & 17.83 & 152.75 & \\
\hline rho & & 41.68 & 23.79 & \\
\hline Mean VIF & & & & 1.08 \\
\hline P-value & 0.00 & 0.00 & 0.00 & \\
\hline BP test & $(351$ & $6)^{* * *}$ & & \\
\hline Hausman test & & (42. & $41)^{* * *}$ & \\
\hline
\end{tabular}


The first step in panel data analysis is to test the random effects (GLS) model and/or the Pooled OLS model as to which is more appropriate. This involves testing whether the data set has specific effects or heterogeneity (ג) using the Breusch and Pagan LM Test. In the relationship between CCC and ROA, the result of the test between the pooled OLS and the random effects model shows that the probability $(\mathrm{p}<0.05)$ value is significant at $1 \%$ level. Therefore, the null hypothesis is rejected in favour of the alternative hypothesis. This indicates that the random effects model is more appropriate than the OLS model. The results of both the pooled OLS and the random effects models can be found in Table 4 above.

The second step is to test the random effects model and the fixed effects model to find which model is more appropriate for this study by using the Hausman Specification Test. Similarly, in the relationship between CCC and ROA, the result of the Hausman test is stated in Table 4 with probability values of 42.41 . The results indicate that the probability $(\mathrm{p}<0.05)$ values are all significant at $1 \%$ level. Therefore, based on the null hypothesis, there is no correlation between error term $\lambda$ and the constants it (RE), whereas based on the alternative hypothesis, there is a correlation between the error term $\lambda$ and the constants it (FE) (Greene, 2003). Thus, the results indicate that the null hypothesis is rejected in favour of the alternative hypothesis that the fixed effects model is more appropriate than the random effects model.

Table 4 presents the regression estimates of the preferred (fixed effect) model on the relationship between cash conversion cycle and its components with ROA. The FE regression model reports the estimates of all the variables, which include the CCC and its three components (ARP, IHP and APP). The model explains the variations in the profitability among the sampled firms. The regression result reported a significant F-value, which indicates the model is fit and all the coefficients in the model are different from zero. The values of the R-square is $7 \%$ which indicates the amount of variance of the SMEs' ROA (profitability) explained by the $\mathrm{CCC}$ and its components.

Although the values of the R-square reported in the regression model is low, nevertheless, it is comparable to similar studies conducted by different scholars. For example, Padachi (2006) reports R-square of $13 \%$. Sharma and Kumar (2011), in different models, reported them as low as $2.4 \%$ and $1.2 \%$. Similarly, Ogundipe et al. (2012), in their study, report R-squares of $11.3 \%, 12.5 \%$ and $00.5 \%$. Also Tauringana and Afrifa (2013) report low R-squares in their study as $10.71 \%, 11.34 \%, 16.09 \%$ and $10.71 \%$. In addition, the intra-class correlation (rho) reported a value of 41.68 in the FE model which implies that the variances are due to differences across the panels. However, the coefficient of intercepts of the model was found to be negative and insignificant. 
The result of the regression estimations of the FE model for the individual variables indicates that the coefficient of cash conversion cycle is found to be negative and insignificant which implies that a decrease in the cash conversion period is associated with an increase in the SMEs' profitability. The finding is in congruence (i.e. support) with Hypothesis 1. The negative relationship found between cash conversion cycle and SMEs' profitability is consistent with the findings of Deloof (2003), Lazaridis and Tryfonidis (2006), Raheman and Nasr (2007), Nobanee et al. (2011) and Ogundipe et al. (2012). However, the insignificant relationship is contrary to the findings of most of the previous studies, which implies that profitable SMEs in Nigeria are less efficient in their working capital management.

With respect to the three components of cash conversion cycle (ARP, IHP \& APP); the coefficient of accounts receivable period was found to be negative and significant. This implies that a decrease in the accounts receivable period by one day is associated with an increase in the SMEs' profitability. This means SMEs managers can create value for the owners by decreasing the days of accounts receivable (García-Teruel \& Martínez-Solano, 2007). The finding fails to support Hypothesis 2. However, the finding is consistent with findings of most previous studies, such as those of Shin and Soenen (1998), Deloof (2003), García-Teruel and Martínez-Solano (2007), Raheman and Nasr (2007), Ogundipe et al. (2012) and Tauringana and Afrifa (2013). Also the finding supports the aggressive policy of working capital management (Tauringana \& Afrifa, 2013).

Further, the coefficient of the inventory holding period shows an insignificant negative relationship with ROA which indicates that an increase in the inventory holding period is related to the decrease in the SMEs' profitability. The insignificant negative relationship between IHP and ROA is similar to the findings in studies conducted by Afeef (2011), and García-Teruel and MartínezSolano (2007) which reveal that an increase in the firm's profitability is associated with the decrease in the inventory holding period and vice-versa. The finding is also consistent with the hypotheses and aggressive working capital strategy, which implies that maintaining low inventory level is associated with an increase in the firm's profitability. However, Mathuva (2010, pp. 8) and BañosCaballero et al. (2012, pp. 519), argued that high inventory level is associated with high profitability as "maintaining high inventory level reduces the cost of possible interruption in the production process and reduces loss of business due to scarcity of products". Similarly, the coefficients of accounts payable period are found to be negative and insignificant.

Furthermore, Table 4 reports the regression estimates of the four control variables used in this study under the fixed effect model. The coefficients of sales growth, leverage and firm age indicate significant positive relationships with a firm's profitability. According to García-Teruel and Martínez-Solano 
(2007), sales growth could be an indicator of a firm's business opportunities and is an important factor which allows firms to earn high profits. Similarly, a firm's profitability increases as the age of the firm increases. This may be due to the good relations established with the firm's suppliers and customers.

\section{Summary, Conclusion and Recommendations}

The main aim of this study was to investigate the relationship between cash conversion cycle and its components with SMEs' profitability proxy by ROA. The study utilised the financial data of 311 samples of Nigerian SMEs observed over a period of seven years from 2007-2013. The empirical findings on accounts receivable period support Hypothesis 2 by reporting a significant negative relationship with ROA. The findings concur with the working capital management theory which proposes shorter accounts receivable period with higher profitability (Deloof, 2003; Raheman \& Nasr, 2007). The findings also suggest that managers can improve their firm's profitability by shortening the accounts receivable period (Deloof, 2003; García-Teruel \& Martínez-Solano, 2007; 2008; Afeef, 2011). However, the association between cash conversion cycle, inventory holding period and accounts payable period with SMEs profitability fail to support Hypotheses 1 and 2 by reporting a non-significant negative association.

Overall, the result of this study shows that only ARP support Hypotheses of the study whereas CCC, IHP and APP fail to support Hypotheses. The plausible explanation is that most Nigerian SMEs are associated with lack of managerial proficiency and poor management of resources (SMEDAN/NBS, 2012; Sunday, 2011; Ademola et al., 2013). Managerial incompetency might lead to poor financial management, particularly efficient working capital management. Moreover, Nigerian SMEs are associated with financial constraints (Okpara, 2011; SMEDAN/NBS, 2012). This affects their ability to employ skilled and competent personnel who can manage their resources effectively. As such, they rely on cheap labour from family members and close associates, which may have negative effects on the firms' performance.

The major contribution of this study is focusing on small and medium-sized entities from a developing nation (Nigeria) and establishing the simultaneous relationship between cash conversion cycle and its components with the profitability of the Nigerian SMEs over a period of seven years. Furthermore, it provides contributions to the body of knowledge in the existing literature with respect to the scope and the methodology applied using the linear model on the balanced panel or longitudinal data. Practically, the study provides SME owners/managers suggestions related to approaches for improving the firms' profitability through efficient management of working capital components. Thus, 
the findings of the study will benefit SME owners/managers and policy-makers in the Nigerian economy by applying efficient working capital management for high performance.

The following are the limitations of the study. First, due to lack of a single or universally accepted definition of SMEs in Nigeria and the world at large, the SMEs captured under this study are limited to those captured in the definition by the Nigerian National Policy on SMEs and registered with SMEDAN and the CAC within the period of the study. Second, the sample firms (SMEs) are limited to the non-financial and non-services firms. Third, SMEs with incomplete data from 2007 to 2013 are not included in the sample of this study. In other words, SMEs with incomplete data during the period of the study and/or not in the register of SMEDAN and the CAC are all excluded from this study. Based on these limitations, future studies should explore the definitions of SMEs by other institutions (e.g. the CBN, FIRS and IFRS) to incorporate and capture them their studies. Adopting this approach will increase the generalizability of the findings. Future studies may also consider SMEs from the financial and services sectors. Hopefully, the effects of the variables under investigation will be explored in relation to firms in the financial and services sectors. Lastly, the period of the study (time frame) should be extended to 2016 and 2017 for accuracy and timely information.

\section{References}

Abuzayed, B. (2012). Working capital management and firms' performance in emerging markets: The case of Jordan. International Journal of Managerial Finance, 8(2), 155-179.

Ademola, I. S., O, O. S., Olusuyi, A. E., \& Edun, F. (2013). Why small scale businesses failed as a remedy to unemployment problem in Nigeria. IOSR Journal of Humanities and Social Science (IOSR-JHSS), 8(4), 68-73.

Afeef, M. (2011). Analyzing the impact of working capital management on the profitability of SME's in Pakistan. International Journal of Business and Social Science, 2(22), 173-183.

Arunkumar, O. N., \& Radharamanan, T. (2012). Analysis of effects of working capital management on corporate profitability of Indian manufacturing firms. International Journal of Business Insights and Transformation, 5(1), 71-77.

Azam, Muhammad, S. I. H. (2011). Impact of working capital management on firms ' performance: Evidence from non-financial institutions of KSE-30 index. Interdisciplinary Journal of Contemporary Research In Business, (2005), 481-492. 
Baños-Caballero, S., García-Teruel, P. J., \& Martínez-Solano, P. (2012). How does working capital management affect the profitability of Spanish SMEs? Small Business Economics, 39(2), 517-529.

Besley, S., \& Brigham, E. (2007). Essentials of managerial finance. Retrieved from https://scholar.google.com/scholar?hl=en\&q=Besley $\% 2 \mathrm{C}+\mathrm{S} . \% 2 \mathrm{C}+$ $\% 26+$ Brigham $\% 2$ C+E.+\%282005\%29.+Essentials+of+managerial+fina nce $+\& b$ tnG $=\&$ as_sdt $=1 \% 2 C 5 \&$ as_sdtp $=\# 0$

Bhaduri, S. (2013). Introduction to Panel Data Analysis, 1-43.

Boonpattarakan, A. (2012). Model of Thai small and medium-sized enterprises' organizational capabilities: Review and verification. Journal of Management Research, 4(3), 15-43.

Charitou, M. S., Elfani, M., \& Lois, P. (2010a). The effect of working capital management. Journal of Business \& Economics Research, 8(12), 63-68.

Charitou, M. S., Elfani, M., \& Lois, P. (2010b). The effect of working capital management on firm's profitability: Empirical evidence from an emerging market. Journal of Business \& Economics Research, 8(12), 63-68.

Deloof, M. (2003). Does working capital management affects profitability of Belgian firms? Journal of Business Finance and Accounting, 30(3), 573-588.

Ebben, J. J., \& Johnson, A. C. (2011). Cash conversion cycle management in small firms: Relationships with liquidity, invested capital, and firm performance. Journal of Small Business \& Entrepreneurship, 3, 381-396.

Fazzari, S. and P. (1993). Working capital and fixed investment: New evidence on financing constraints on JSTOR. Retrieved from http://www.jstor.org/ stable/2555961?seq=1\#page_scan_tab_contents

Field, A. (2009). Discovering statistics using SPSS. Retrieved from https:// scholar.google.com.my/scholar?hl=en\&q=Field $\% 2 \mathrm{C}+\mathrm{A} .+\% 282005 \%$ 29.+Discovering+Statistics+Using+SPSS+for+Windows\&btnG=\&as_ sdt=1\%2C5\&as_sdtp=\#0

Filbeck, G. (2005). An analysis of working capital management results across industries. Mid-American Journal of Business, 20(2), 11-18.

Garcia-Teruel, P. J., \& Martinez-Solano, P. (2010). Determinants of trade credit: A comparative study of European SMEs. International Small Business Journal.

García-Teruel, P. J., \& Martínez-Solano, P. (2007). Effects of working capital management on SME profitability. International Journal of Managerial Finance, 3(2), 164-177.

Gill, A., Biger, N., Mathur, N., Palmer, S., Street, W. H., \& Vb-k, B. C. (2010). The relationship between working capital management and profitability: Evidence from the United States. Business and Economics Journal, 2010, 1-9.

Gitman, L. J. (1974). Estimating corporate liquidity requirements: A simplified approach. The Financial Review, 9(1), 79-88. 
Hayajneh, O., \& Yassine, F. (2011). The impact of working capital efficiency on profitability-an empirical analysis on Jordanian manufacturing firms. International Research Journal of Finance and Economics, 66, 67-76.

Howorth, C., Peel, M., \& Wilson, N. (2000). Late payment and credit management in the small firms sector: Some empirical evidence.

Karadagli, E. (2013). Profitability effects of cash conversion cycle: Evidence from Turkish companies. Актуальні Проблеми Економіки, 3(141), 300-310.

Kaur, H. V., \& Singh, S. (2013). Managing efficiency and profitability through working capital: An empirical analysis of BSE 200 Companies, 5(2), 197-207.

Lazaridis, I., \& Tryfonidis, D. (2006a). Relationship between working capital management and profitability of listed. Journal of Financial Management and Analysis, 19(1), 26-35.

Lazaridis, I., \& Tryfonidis, D. (2006b). Relationship between working capital management and profitability of listed. Journal of Financial Management and Analysis, 19, 26-35.

Majeed, S., Makki, M. A. M., Saleem, S., \& Aziz, T. (2013). The relationship of cash conversion cycle and profitability of firms: An empirical investigation of Pakistani firms. Journal of Emerging Issues in Economics, Finance and Banking, 1(1), 35-51.

Mathuva, D. M. (2010). The Influence of working capital management components on corporate profitability: A survey on Kenyan-listed firms. Research Journal of Business Management.

Mathuva, D. M. (2014). An empirical analysis of the determinants of the cash conversion cycle in Kenyan-listed non-financial firms. Journal of Accounting in Emerging Economies, 4(2), 175-196.

Muhammad, M., Jan, W. U., \& Kifayat, U. (2010). Working capital management and profitability an analysis of firms of textile industry of Pakistan. Journal of Management Science, VI(2), 155-165.

Nobanee, H., Abdullatif, M., \& AlHajjar, M. (2011). Cash conversion cycle and firm's performance of Japanese firms. Asian Review of Accounting, 19(2), 147-156.

Nobanee, H., \& Ellili, N. (2015). Working capital management and performance of kuwait construction companies. Corporate Ownership and Control, 12(2), 349-355.

Ogundipe, S. E., Idowu, A., \& Ogundipe, L. O. (2012). Working capital management, firms' performance and market valuation in Nigeria, (1), 19-23.

Okpara, J. O. (2011). Factors constraining the growth and survival of SMEs in Nigeria: Implications for poverty alleviation. Management Research Review, 34(2), 156-171.

Padachi, K. (2006). Trends in working capital management and its impact on firms' performance: An analysis of Mauritian small manufacturing firms. International Review of Business Research Papers, 2(2), 45-58. 
Raheman, A., \& Nasr, M. (2007). Working capital management and profitability - Case of Pakistani firms. International Review of Business Research Papers, 3(1), 279-300.

Raheman, A., Qayyum, A., \& Afza, T. (2011). Sector-wise performance of working capital management measures and profitability using ratio analysis. Interdisciplinary Journal of Contemporary Research in Business, 3(8), 285-303.

Ramachandran, Azhagaih and Janakiraman, M. (2009). The relationship between working capital management efficiency and EBIT. Managing Global Transitions, 1(7), 75-100.

Richards, V., \& Laughlin, E. (1980). A cash conversion cycle approach to liquidity analysis. Financial Management. Retrieved from http://www. jstor.org/stable/3665310

Sabri, T. B. (2012). Different working capital polices and the profitability of a firm. International Journal of Business and Management.

Samson, A., Mary, J., \& Yemisi, B. (2012). The impact of working capital management on the profitability of small and medium scale enterprises in Nigeria. ... Journal of Business Management. Retrieved from http:// docsdrive.com/pdfs/academicjournals/rjbm/2012/61-69.pdf

Sharma, A. K., \& Kumar, S. (2011). Effect of working capital management on firm profitability empirical evidence from India. Global Business Review, 12(1), 159-173.

Shin, H., \& Soenen, L. (1998). Efficiency of working capital management and corporate profitability. Financial Practice and Education, 37-45.

Smith, M., \& Begemann, E. (1997). Measuring association between working capital and return on investment. South African Journal of Business Management, 28, 73-84.

Soenen, L. (1993). Cash conversion cycle and corporate profitability. Journal of Cash Management, 13(4), 53-58.

Stewart, G. (1995). Supply chain performance benchmarking study reveals keys to supply chain excellence. Logistics Information Management, $8(2), \quad 38-45$. Retrieved from http://www.emeraldinsight.com/doi/ pdf/10.1108/09576059510085000

Sunday, K. J. (2011). Effective working capital management in small and medium scale enterprises (SMEs). International Journal of Business \& Management, 6, 271-279.

Takon, S. M. (2013). Does cash conversion cycle have impact on return on assets of Nigerian firms? Research Journal of Finance and Accounting, 4(14), 34-43.

Tauringana, V., \& Afrifa, G. A. (2013). The relative importance of working capital management and its components to SMEs \& apos; profitability. Journal of Small Business and Enterprise Development, 20(3), 453-469. 
Toby, A. J. (2007). Financial management modelling of the performance of Nigerian quoted small and medium-sized enterprises. Journal of Financial Management and Analysis, 20(1), 49-68.

Tsagem, M. M., Aripin, N., \& Ishak, R. (2015). Impact of working capital management, ownership structure and board size on the profitability of small and medium-sized entities in Nigeria. International Journal of Economics and Financial Issues, 5(Special Issue), 77-83.

Wilson, N. (1997). An investigation into payment trends and behaviour in the UK. CMRC Centre, Leeds University Business School, .... Retrieved from http:// www.cmrc.co.uk/wp-content/uploads/PaymentTrendsandBehaviour.pdf

Yazdanfar, D. (2013). Profitability determinants among micro firms: Evidence from Swedish data. International Journal of Managerial Finance, 9(2).

Yazdanfar, D., \& Öhman, P. (2014). The impact of cash conversion cycle on firm profitability. International Journal of Managerial Finance, 10(4). 